THEORETICAL FOUNDATIONS OF THE FUNCTIONING OF EDUCATION. WAYS TO

IMPROVE THE EFFECTIVENESS OF EDUCATIONAL ACTIVITIES

\title{
1.8 Професійна підготовка майбутніх спеціалістів в технічному університеті: основні завдання
}

Економічні та соціальні зміни, які мають місце в нашій країні, пред’являють до майбутніх фахівців високі вимоги, тому зростає відповідальність закладів вищої освіти за якість професійної підготовки. Освітнім установам надаються повноваження при визначенні стратегії розвитку, концепцій, організаційних методів роботи в навчанні студентів, а це додаткова відповідальність за результати своєї освітньої діяльності. Таким чином навчальні заклади стоять перед необхідністю розробки програм, які б гарантували досягнення поставлених цілей в освітньому процесі.

Необхідною є підготовка професіоналів, яка відповідає вимогам галузевих ринків та важливим є формування особистості, здатної вирішувати проблеми, планувати та реалізовувати плани. Розвиток суспільства i, як наслідок, зміна структури промисловості в Україні ставить перед вчорашніми школярами нелегкий вибір - вибір спеціальності. Як слушно помітив А. Адлер професійна діяльність (так як дружба і любов) є найкращою цінністю людини. В той же час I. Бех зауважив, що найбільш чутливий до соціальних, економічних, політичних та моральних перетворень є вік юності [78, с. 245].

Відомий американський психолог Е. Еріксон, аналізуючи 8 етапний життєвий цикл людини, багато уваги приділив кризі ідентичності особистості саме в юнацькому віці $(11-20$ років). Під ідентичністю вчений розумів процес психічної діяльності, завдяки якій людина оцінює себе 3 точки зору оцінок ії іншими, особливо групами однолітків; це пошук свого власного "Я", серія соціальних та індивідуально-особистісних виборів, ідентифікація та самовизначення. Для молодої людини не просто проаналізувати та узагальнити все, що вона знає про себе та об’єднати ці знання в ідентичність своєї особистості, яка дає можливість усвідомити своє минуле і майбутнє, яке логічно випливає з нього. Процес формування особистості в студентському віці трьохкомпонентний: внутрішній план (молода людина сама створює свій імідж), зовнішній план (інші значущі люди бачать ідентичність та цілісність 
THEORETICAL FOUNDATIONS OF THE FUNCTIONING OF EDUCATION. WAYS TO IMPROVE THE EFFECTIVENESS OF EDUCATIONAL ACTIVITIES

особистості), узгодженість внутрішніх та зовнішніх планів. Розмитість ідеалів характеризується повним або частковим несприйняттям цінностей, світогляду та ідеології сім’ї та інших авторитетів молодою людиною. На формування ідентичності іноді негативно впливають соціальні групи 3 якими людина ідентифікує себе (зірки шоу бізнесу, відомі спортсмени, політичні діячі), оскільки нівелюється унікальність особистості і таким чином обмежується формування їі ідентичності.

Нездатність молодих людей до формування їхньої ідентичності - криза ідентичності - призводить до проблем 3 вибором кар'єри, продовженням навчання, виникає відчуття власного незадоволення, душевного розладу i безцільності. Іноді молоді люди мають негативну ідентичність - вони не хочуть дотримуватись норм свого суспільства і однолітків та обирають негативні моделі поведінки для наслідування. Успішний вихід 3 кризи періоду юності характеризується вірністю, яка розуміється як здатність молодої людини бути вірним своїм прихильностям і обіцянкам, незважаючи на неминучі протиріччя в ii системі цінностей (Е. Еріксон). Вірність - наріжний камінь ідентичності, здатність молоді приймати і дотримуватися моралі, етики та цінностей суспільства [83].

Неабияке значення в студентському віці має здатність до побудови особистісних перспектив - спрогнозувати та уявити своє майбутнє усвідомлюючи всі труднощі та проблеми на шляху по досягненню бажаного результату і готовність подолати всі перешкоди до поставленої мети. К. Абульханова-Славская підкреслює, що особистісна перспектива є показником зрілості людини та їі здатності організувати час [77, с. 24].

Формування поглядів студентів залежить від виховання, переконань та набутих знань, але життєві позиції можуть змінюватись, тому правильний вибір професії є основною умовою успішної кар'єри. Успішною професійна кар’єра буде лише у тому випадку, якщо студент не просто знає чого хоче, але й навіщо це йому, як досягнути мети та буде спрямувати активні дії в досягненні успіху в професійній діяльності. 
Аналізуючи власні здібності та уподобання абітурієнт не схильний до технічних наук не вибере IT- спеціальність, і в свою чергу, випускник школи, який захоплювався математикою та інформатикою, навряд чи буде поступати в університет на історичний чи юридичний факультет. На вибір університету та спеціальності впливає багато чинників. Згідно з опитуванням, проведеним О. Кучерук серед студентів та викладачів факультету прикладної математики та комп'ютерних технологій Хмельницького національного університету на питання « Які фактори найбільше вплинули в свій час на Ваш вибір професії?» були отримані результати, представлені на рисунку $1[81$, с.65].

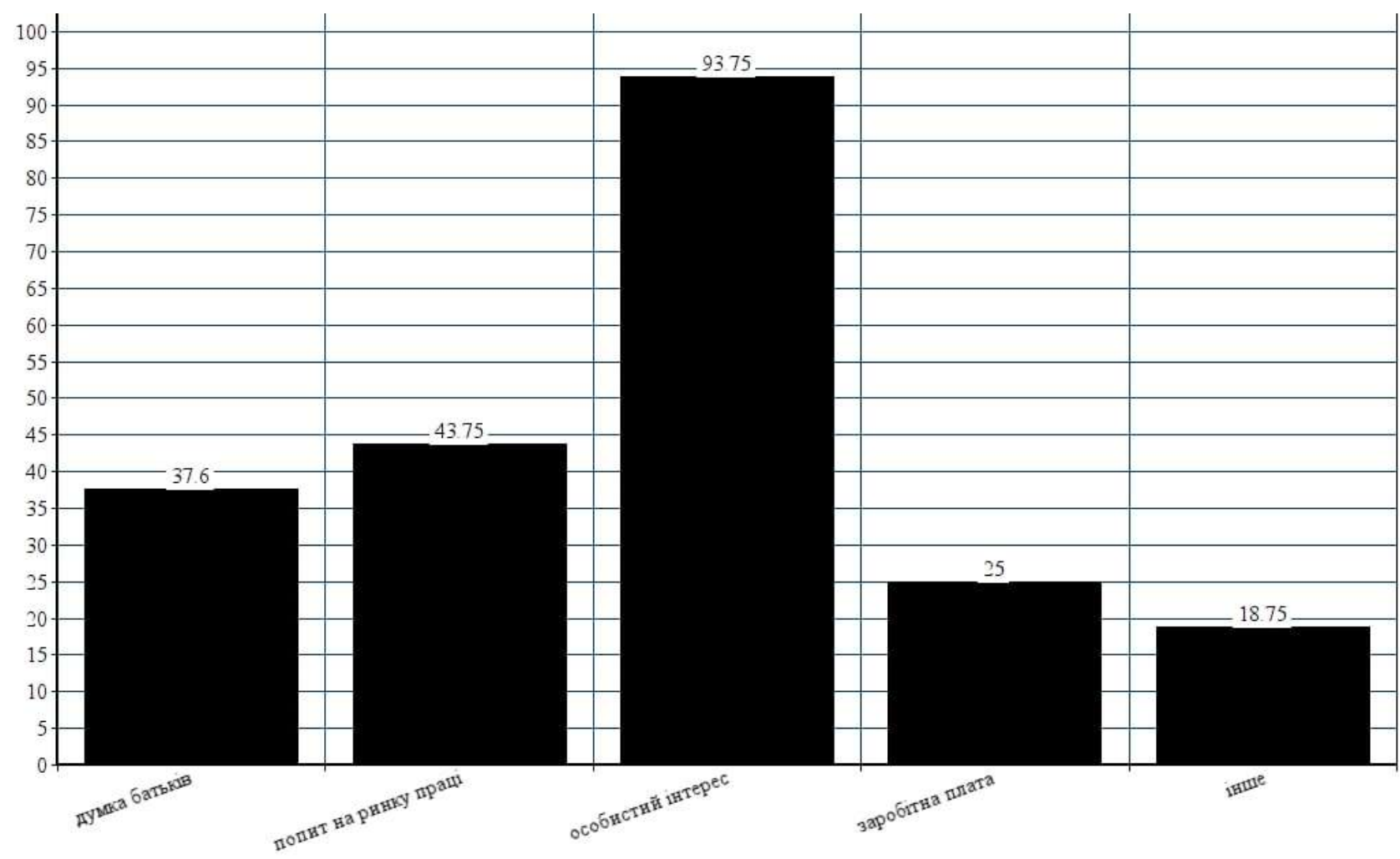

Рис.1 Фактори, які впливають на вибір професії.

Вчена Ю. Корницька в рамках свого дослідження опитала студентів чотирьох технічних університетів різних міст України (Києва, Одеси, Донецька та Черкас) з чим у них асоціюється успіх. Відповіді студентів з усіх вишів були однакові: на перше місце було поставлено матеріальне забезпечення, потім кар'єра, далі - набуття влади, потім: громадське визнання, особисті досягнення, висока кваліфікація. На останньому місці була творча самореалізація [79, с.151.]. 
THEORETICAL FOUNDATIONS OF THE FUNCTIONING OF EDUCATION. WAYS TO

IMPROVE THE EFFECTIVENESS OF EDUCATIONAL ACTIVITIES

Однак аналізуючи питання виховання студентів I. Бех писав, що професійну діяльність треба розглядати як пошук покликання, життєвого призначення та особистої самореалізації, а не як невідворотний тягар життя [ 78, с. 245].

Таким чином, перше завдання вищої освіти - виховати професіонала, який в своїй діяльності буде бачити шляхи самореалізації, а не шляхи заробітку чи збагачення.

У 2018 році серед студентів 4 курсу факультету прикладної математики НТУУ «КПІ ім. Ігоря Сікорського» спеціальностей: «Комп’ютерна та системна інженерія», «Програмна інженерія», «Інженерія програмного забезпечення» було проведене опитування. На запитання «Визначте до чого Ви прагнете в своїй майбутній професійній діяльності» були запропоновані наступні відповіді: матеріальне забезпечення, повага оточуючих, самореалізація, професійне зростання, кар'єра.

В результаті 69\% респондентів надали перевагу самореалізації, а не матеріальному забезпеченню. Ми вбачаємо в цьому свідоме ставлення до майбутньої професії та деякий вже існуючий досвід професійної діяльності. Студенти усвідомлюють, що одноманітна рутинна робота не зможе задовольнити їх потреби в постійному саморозвитку. Тільки займаючись цікавою та складною справою майбутні спеціалісти зможуть підвищити свій професійний рівень та як результат отримати матеріальну винагороду.

В той же час, по матеріалам досліджень Г. Міхненко, 78\% опитаних нею студентів НТУУ «КПІ ім. Ігоря Сікорського» вважають, що в результаті навчання вони отримують те, до чого прагнули, вступаючи до вишу, але наряду 3 цим 46\% опитаних студентів вважають, що головне - це отримати диплом, а оцінки і рівень знань не мають значення [82, с. 48]. На нашу думку, зі студентами, які не розуміють цінності знань та навичок набутих під час навчання має проводитись виховна та роз'яснювальна робота. Оскільки конкуренція на ринку праці дуже жорстока, то наявність диплома без грунтовних знань не забезпечить людину роботою по спеціальності. Студентські роки - безцінний час для 
THEORETICAL FOUNDATIONS OF THE FUNCTIONING OF EDUCATION. WAYS TO

IMPROVE THE EFFECTIVENESS OF EDUCATIONAL ACTIVITIES

ефективної акумуляції знань з їх подальшим застосуванням під керівництвом викладачів.

До речі, дослідниця Т. Котмакова наводить дані, що на запитання: “Чи пов’язана Ваша майбутня спеціальність з творчою діяльністю” більш ніж 75\% опитаних нею студентів відповіли заперечно, а на запитання: “Ви творча людина?” ствердно відповіли лише $36 \%$ опитаних студентів [80, с. 116].

Ми в 2020 задали студентам факультету прикладної математики НТУУ «КПІ ім. Ігоря Сікорського» схоже запитання: «Чи стикаєтесь Ви під час навчання з завданнями, які потребують творчого підходу? Наведіть приклади.» В результаті 97\% студентів вважають, що творчий підхід необхідний не тільки для гуманітарних а і для технічних предметів - розрахункові, курсові та лабораторні роботи потребують нестандартного підходу та творчого мислення.

В той же час Г. Міхненко наводить, у своїй роботі [82, с. 62.], перелік загальних та професійних компетентностей студентів НТУУ «КПІ ім. Ігоря Сікорського» спеціальності “Електромеханічні системи автоматизації та електропривод”, де на рівні з вимогами відносно теоретичних та технічних знань та знань технічного обладнання, окремо зазначена здатність до ділових комунікацій та ділового спілкування. Таким чином, другим завданням вишу є навчання студентів діловому спілкуванню.

Навчатися діловому спілкуванню означає, що ваші дії повинні відповідати встановленим діловим регламентом правилам і обмеженням, які визначаються різними факторами, ступенем офіційності ситуації, яка обумовлює дотримання певних правил спілкування. Для майбутніх фахівців важливо володіти культурою ділового спілкування, яка сприяє встановленню і розвитку відносин співробітництва між колегами, керівниками i підлеглими, партнерами i конкурентами. Для успішного вирішення завдань, що стоять перед співробітниками, визначається спрямованість ділового спілкування на забезпечення умов для плідної співпраці. На дотримання правил впливають також національні та культурні особливості учасників, а також цілі і завдання конкретної зустрічі, бесіди, презентації, конференції. Отже, варто проводити 
THEORETICAL FOUNDATIONS OF THE FUNCTIONING OF EDUCATION. WAYS TO

IMPROVE THE EFFECTIVENESS OF EDUCATIONAL ACTIVITIES

навчання ділового спілкування в певних формах (ділова розмова, ділове обговорення, ділові переговори) з використанням ділового етикету та етикетних мовних зворотів. Кожній ролі учасників спілкування відповідають певні завдання, які необхідно враховувати і вести себе відповідно до вимог, що пред'являються конкретною обстановкою, щоб спілкування було ефективним, воно повинно базуватись на правилах, які сприяють розвитку співпраці.

У зв’язку з глобалізацією світової економіки та ринку праці постає нагальна потреба у володінні іноземною мовою. Визначимо трете завдання: навчання студентів іноземної мови на новому рівні, як інструменту без якого спеціаліст не може виконувати свої професійні функції.

В багатьох сферах життя відбуваються суттєві зміни 3 розвитком та вдосконаленням технологій, дізнатись про які першим можна володіючи англійською мовою - мовою інтернаціонального спілкування. Вся наукова спільнота обмінюється думками та відкриттями на сторінках англомовних наукових видань. Отже для того, щоб бути обізнаним з останніми здобутками видатних вчених в певній сфері та самому представляти свої ідеї та відкриття на світовому ринку молодому спеціалісту необхідно вільно володіти іноземною мовою.

На українському ринку працює багато компаній з іноземним капіталом, співбесіда на стажування в які відбувається іноземною мовою. Тобто володіння іноземною мовою із додаткової позитивної якості кандидата на посаду перетворюється на обов’язкову вимогу.

Четверте завдання - створити впевнену в собі, ініціативну людину, яка здатна буде навчатись все життя i, при потребі, змінити не лише місце роботи, а й спеціальність. А для того потрібно аби вона навчалась із задоволенням i відчувала викладача не як вчителя з японських фільмів, а як доброго старшого наставника 3 американських. Тобто кожен студент має відчувати себе в університеті комфортно, знаходячись в атмосфері доброзичливості та допомоги - ідеальному середовищі для саморозвитку та самовдосконалення. 
THEORETICAL FOUNDATIONS OF THE FUNCTIONING OF EDUCATION. WAYS TO

IMPROVE THE EFFECTIVENESS OF EDUCATIONAL ACTIVITIES

Для викладача така позиція “старшого товариша” та радника складніша, ніж позиція “фельдфебеля”, якому всі повинні підкорятися, якого треба боятися бо він може поставити низький бал, чи взагалі не поставити жодного. “Старший товариш" собі такого дозволити не може, бо студенти не підлеглі, а «колеги», i кожного треба зацікавити своїм предметом, провести заняття так, аби не було монологу, аби всі присутні приймали активну участь у занятті. Ми цілком згодні 3 думкою Ю. Корницької, щодо необхідності “демократизації учасників педагогічного процесу”[79]. Цю ідею розвиває Г. Міхненко підкреслюючи, що потрібна “зміна функцій учасників освітнього середовища університету, коли викладач $€$ не лише транслятором знань, а й модератором інтелектуальної діяльності студентів, за якої останні стають активними перетворювачами інформації...” [82, с. 10]. Але чи дійсно все залежить від викладача? Чи досить підготувати кольорові слайди, чи зробити захоплююче слайд-шоу або відео щоб захопити увагу студента?

Сучасний викладач намагається викладати свій предмет таким чином, щоб задовольнити потреби студентів, акцентуючи на використанні тих чи інших тем в їх подальший практичній діяльності. Щоб оптимізувати навчальний процес викладачу варто провести опитування серед студентів щодо їх потреб та знайти шляхи їх задоволення. Таким чином студенти будуть залучені до створення вектору викладання, відчують, що їх думка важлива для викладача і сприятлива атмосфера взаємоповаги та взаєморозуміння буде створена.

В сучасному університеті відбуваються демократичні перетворення і більше залучення студентів не тільки до навчального процесу, а й до роботи університету в цілому. Представники студентської ради та профспілкового комітету студентів входять до складу вченої ради, студенти також приймають участь у виборах деканів своїх факультетів та ректора університету.

На постійній основі за ініціативою студентського активу на всіх факультетах НТУУ «КПІ ім. Ігоря Сікорського» проводяться опитування серед студентів 3 приводу якості викладання дисциплін викладачами. Результати опитувань представлені діаграмами і доступні на сайтах факультетів. Основна 
мета опитувань - надати зворотній зв'язок, показати над чим викладачу потрібно замислитись, що змінити в своїй роботі, як удосконалити певні якості, щоб студентам було ефективніше та комфортніше навчатись. За результатами опитувань студенти, які ще не знайомі з викладачем можуть уявити собі його. Наведемо основні критерії оцінювання, які студенти вважають найсуттєвішими:

1. Актуальність матеріалу.

2. Ввічливість.

3. Своєчасність та достатність інформування.

4. Доступність матеріалів.

5. Об'єктивність оцінювання.

6. Пунктуальність.

7. Змістовність занять.

8. Володіння матеріалом з дисципліни.

Базуючись на відповідях студентів створюються два графіки: задоволення викладанням дисципліни та самооцінка власних знань після проходження курсу. Після ще двох показників: предмет викладача не можна закрити без знань та система оцінювання викладача, підводиться підсумок: наскільки студенти ( у відсотках) задоволені роботою викладача в цілому.

Також в університеті існує офіційне опитування, яке проводиться на внутрішньо університетському сайті. Воно складається із 5 запитань: 1) Об'єктивність оцінювання. 2) Вміння донести матеріал до студентів. 3) Вміння налагодити партнерські стосунки зі студентами. 4) Доброзичливість та тактовність по відношенню до студентів. 5) Використання засобів дистанційного спілкування ( засоби відеозв'язку, месенджери тощо). Студенти оцінюють викладачів за 5 бальною системою. Відповіді анонімні, результати представлені по курсах та в цілому.

3 розвитком соціальних мереж студенти можуть написати подяку чи навпаки описати проблемну ситуацію, яка виникла 3 викладачем в певних телеграм чатах. Така миттєва зворотна реакція сприяє в деякій мірі уникненню 
THEORETICAL FOUNDATIONS OF THE FUNCTIONING OF EDUCATION. WAYS TO

IMPROVE THE EFFECTIVENESS OF EDUCATIONAL ACTIVITIES

конфліктів, хоча на нашу думку в суперечливій ситуації завжди можна досягти компромісу, не виносячи іï на загальне обговорення в соціальних мережах.

Таким чином, для роботи сучасної вищої школи має відбуватись постійне самовдосконалення та саморозвиток як студентів так i викладачів. Для оптимізації навчально-виховного процесу відносини між його учасниками слід будувати на основі партнерства, поваги та взаємодопомоги. 